\title{
Emotional Reflexivity in Contemporary Friendships: Understanding It Using Elias and Facebook Etiquette
}

\author{
by Mary Holmes \\ Flinders University \\ Sociological Research Online, 16 (1) 11 \\ <http://www. socresonline.org.uk/16/1/11.htm/> \\ $10.5153 /$ sro.2292
}

Received: 3 Aug 2010 Accepted: 18 Feb 2011 Published: 28 Feb 2011

\begin{abstract}
The popular social networking site Facebook has become a part of millions of people's everyday lives. In order to help people navigate the friendships they form and maintain on Facebook there are many websites offering advice about etiquette. This advice, and responses to it, can help reveal how contemporary emotional expression is organised, especially as it relates to friendship. This paper critically adapts the approach of other sociologists such as Norbert Elias, and Cas Wouters who have used etiquette and advice books to explore social changes in emotionality. Using online advice about Facebook etiquette, it is argued that there is uncertainty about the degree of emotional closeness appropriate for friendships in contemporary life, especially where there are status differences. It is difficult to know how to feel and how to behave within the relational complexity of contemporary life. In particular, expanded definitions of friendship form part of this complexity which promotes and requires an 'emotionalisation of reflexivity'.
\end{abstract}

\section{Keywords: Emotion, Friendship, Elias, Manners, Facebook, Reflexivity}

\section{Introduction}

The popular networking site [Facebook] ... is revealed as a minefield of etiquette blunders, social gaffes and narcissistic indulgences to which the offending parties are completely oblivious, much to the aggravation of their "friends" (Harris cited on Lyons 2007).

1.1 Being friends on social networking sites such as Facebook can be difficult. Innumerable websites advise people on the proper etiquette to observe in using Facebook, in order to avoid 'blunders' and save them from aggravating their friends or embarrassing themselves. This advice can reveal much about contemporary emotionality, or ways of being emotional. Such information is crucial in creating a robust sociology that includes attention to the emotional lives of individuals within social systems (Davetian 2005). There is a small body of sociological analysis of etiquette and advice books which provides such analysis of emotionality (Elias 2000; Hochschild 2003; Wouters 2007; 2004; 1995a; 1995b). This emotionality has many important aspects including gender differences (see Hochschild 2003), but here I focus on general social changes over time. Norbert Elias (2000/1939) charts a formalizing of manners and increased emotional restraint from the medieval to the end of the nineteenth century. Cas Wouters (2007; 2004; 1995a; 1995b) argues that this was followed by informalization in the twentieth century, which enabled greater diversity of emotional expression, but required more regulation. Hochschild (1983) has described greater regulation in terms of more management according to dominant feeling rules (e.g. Hochschild 1983). In the twenty-first century it is possible that we are seeing the beginnings of another shift in which the individualized disciplining, or managing, of emotionality is being replaced by a more complex relational negotiation of emotional norms that can be characterized as an 'emotionalization of reflexivity'. Reflexivity is defined as the practices of altering one's life as a response to knowledge about one's circumstances. Emotionalisation describes both the need for theories of reflexivity that recognize emotions as key to thinking and acting and a process whereby detraditionalization means that people rely more on emotions than past practices in reflexively shaping their lives (Holmes 2010).

1.2 Some insight into emotionalized reflexivity can be gained from internet texts about Facebook etiquette. Facebook is the largest social networking site with over 500 million users, up from around 300 million when I began this research in 2008 (Facebook 2011). Sociological literature on social networking sites confirms that users have often struggled to agree on how the sites should be used (see Boyd and Ellison 2007; 
Hardey 2008a; Wellman 2001). Judging by the amount of advice available and the comments it draws, online advice appears important in shaping norms about how to relate using Facebook. These internet sources illustrate contested norms and ideals about how one should feel and behave. However, it is not possible to entirely distinguish the descriptive from the prescriptive (Seidman 1991: 6) because users share their experiences and use them as a basis for advising others. Advice is given via blogs, online magazines and newspapers. As a whole, these sites give a very good picture of the kinds of concerns around relating to others that new technologies like social network sites raise and represent.

1.3 As 'the internet has become another mode of communication in people's everyday lives' (Helsper and Whitty 2010: 916), the possibilities and pitfalls it presents require new manners, or 'netiquette'. There are some continuities but netiquette has changed over a relatively short time as the technology and the type and context of online interactions has altered (see Beer and Burrows 2007). For example, in the 1990s email etiquette was discussed by users. Much of the advice still seems relevant in the more interactive formats of web 2.0. Emailers are advised to 'assume that any message you send is permanent, to 'have in mind a model of your intended audience', to 'avoid responding while emotional' and to 'assume the honesty and competence of the sender'. However, the other advice given seems less pertinent in the world of social networking. It seems less necessary to say 'do not insult or criticise third parties without giving them a chance to respond' and unthinkable to suggest that users 'avoid irrelevancies' (Sproull and Kiesler 1991: 54). As the following analysis suggests, if third parties are part of the network they always have 'a chance to respond' and the leisure and friendship oriented nature of most online social networking now encourages 'irrelevancies', unlike the more work oriented email form. There have been changes in the kind of relationships computers mediate and how. The scholarly literature on computer mediated communication shifted from early concern about online relationships as encouraging 'uninhibited and aggressive' communication, to acknowledgement that meaningful friendships and even romantic relationships can be formed and maintained online (Baker and Whitty 2008; Helsper and Whitty 2010: 916; Mantovani 1994; Sproull and Kiesler 1986; Valentine 2006; Whitty 2008). Social networking sites are now key online platforms for meaningful relationships.

1.4 Social media form not so much a new space for relating as an extension of the 'real' world (Hardey 2008a). Thus, they provide a useful window on changes around emotions. Most people use sites like Facebook to interact in familiar ways with people they already know (boyd 2008; Hardey 2008a; Lenhart 2009, Skinstad 2008), but there are also numerous opportunities for confusion (boyd 2008: 126). This paper focuses on the confusions around making, maintaining and breaking links with online 'friends'. The first section of the paper reviews relevant literature about changes in the emotional content of social relations and especially friendships. In the second section I outline the method of textual analysis used to explore Facebook etiquette. The following sections introduce the three major themes that emerged from the data. The first theme is uncertainty about how emotionally close different friendships should be, especially where there are differences in social position. The second theme is the difficulty of managing emotions within diverse online networks. The third theme relates to how Facebook etiquette indicates the emotional nature of reflexivity within this relational complexity, especially given expanded definitions of friendship.

\section{Emotional friendships}

2.1 Emotionally close friendships supposedly prosper within contemporary societies where egalitarian relationships are seen as the ideal (Allan 1998; Budgeon 2006; Pahl 2000; Roseneil 2005). Norbert Elias and the Elisian scholar Cas Wouters can help explain how this has come about. Elias argues that from the eleventh century up until the nineteenth, individuals have been expected to exercise increasing selfrestraint over their bodily and emotional needs. A study of manners based on etiquette books reveals how major socio-historical processes alter, without completely determining, how people feel. For Elias (2000/1939: 71), analyzing these books reveals social processes about which we have 'very little direct information' (Elias 2000/1939: 72)[1]. The overall civilizing process involves a number of subsidiary processes: socialisation, rationalisation, individualisation and pacification. Socialisation refers to how children are taught to control their bodies and emotions. This process also occurs within societies as they mature. Bodies and emotions are increasingly shaped around social expectations. More formal manners are expected as modernity emerges, assisted by the introduction of new technologies like forks, handkerchiefs and toilets. As rationalisation processes take hold emotions are subject to more regulation. Societies during this period also experience individualisation, which entails a change of consciousness that sees communal practices recede. People stop drinking from the same glass, and eating from a common dish. They come to define their emotions in individual terms rather than as integral to kinship and local ties. In addition, state formation is central to the civilizing process in that the state monopolises the 'acceptable' use of violence as part of the process of pacification (Elias 2000; Wouters 2004). Elias employs a basically Freudian 'repressive hypothesis', which neglects that power does not always say 'no'; power can produce individuals and the relations between them (Foucault 1979). The resulting social practices and processes cannot always be firmly categorised as 'civilised' and emotional trends are ambivalent. They are as likely to tend towards increased conflict as they are to be examples of more civilised, socialised, rationalised and pacified social relations (Burkitt 1996). This slightly revised version of an Eliasian approach helps us understand changes in emotionality as requiring greater reflexivity to deal with less rigid, more informal practices around feelings and relationships.

2.2 Cas Wouters (1995a, 1995b, 2004) continues the story Elias tells, charting an informalisation of manners in the twentieth century. He uses American, Dutch, English and German etiquette books to illustrate changes in the relations between individuals and social groups. The civilizing process continues but 'as national, continental and global integration processes exert pressure towards increasingly differentiated regimes of manners, they also exert pressure towards increasingly reflexive and flexible regimes of self-regulation' (Wouters 2004: 210). New ways of making money emerge and thus status barriers develop greater permeability, whilst self-restraint becomes more crucial. An examination of etiquette reveals alterations in regimes of power and emotions because '[o]ne of the functions of etiquette is to draw and maintain social dividing lines' (Wouters 1995a: 108). Manners extend amongst a wider group 
keen to portray themselves as cultured. Social divides, especially those around class and sex break down in the twentieth century (Wouters 1995a, 1995b):

As low status groups have experienced some liberation from the 1960s, the maintenance of social distance via manners has become less crucial but a level of detachment in viewing oneself and others has become necessary. Manners previously taken for granted are questioned. People ask 'why is this forbidden and that permitted or prescribed?' (Wouters 2004: 196).

2.3 As more egalitarian relations are favoured, although with national differences, friendships can become more emotionally open (Wouters in this volume). Expressing ones emotions becomes expected within close friendship relations based on trust, reciprocity and intimacy (Allan 1998; Pahl 2000, Spencer and Pahl 2006). However, these friendship ideals do rely on the possibility of having a relatively equal relationship, otherwise reciprocating can become problematic and trust and intimacy can be threatened if one friend feels vulnerable in the face of the other's superior social status (Bjornberg this volume). The kind of 'liberation' of low status groups that Wouters notes, can also be conceived of as an example of diffusion in power/knowledge (Foucault 1979) which brings more questions about what is acceptable, when and with whom? Feeling rules that stipulate how people should feel in different social situations (Hochschild 1983) are included in this questioning (Holmes 2004) and people may struggle to decide where social dividing lines now lie. Emotion management becomes problematic as social change complicates social relations and makes feeling rules uncertain.

2.4 Relational complexity can be difficult to deal with emotionally, as traditional practices fade. The individualisation thesis (Bauman 2003; Beck and Beck-Gernsheim 1995; 2002; Giddens 1992) posits a weakening of intimate relationships as social life becomes more fragmented, but this does not fully capture the impact of expanding behavioural and emotional alternatives (Holmes 2010). More impression management (Goffman 1987) is required, although emotions may sometimes overwhelm attempts to manage them (Holmes 2004, 2010, Mills and Kleinman 1988). Modernity sees each individual inhabit a variety of roles and sometimes this can cause 'role conflict'. People play different roles for different others, so that someone behaves differently as a granddaughter than as a friend. The segregation of different audiences is important in 'allowing the individual to possess contradictory qualities'; but if that segregation breaks down '[t]he embarrassment and vacillation characteristic of role conflict presumably result' (Goffman 1961: 91). The intention here is not detailed engagement with, nor revival of, role theory. However, role conflict is a useful term in studying social networking as a key example of the complexity of relationality and emotionality under contemporary social conditions.

2.5 The relational complexity partly evidenced by social networking etiquette is particularly characterized by expanded definitions of friendship (Budgeon 2006, Pahl and Spencer 2004, Spencer and Pahl 2006) which require emotional reflexivity. Whether social change has brought an 'emotional cooling' (Hochschild 2003; Stearns, 1994) or more informal and perhaps 'warmer' emotional styles (Wouters 2004), people must reflexively engage with emotions as they relate to others within different contexts (Holmes 2010). Feeling rules focus on emotional control, a control that Elias and Wouters both suggest is increasingly required of individuals, first as self-restraint is formalized and then as it becomes part of the reflexivity required as informalisation occurs. The development of internet technology assists this informalisation. Using online advice on Facebook etiquette I argue that feeling rules are shifting quickly and uncertain, so that 'management' is problematic and reflexivity necessary.

\section{A textual analysis of online Facebook etiquette advice}

3.1 Online advice about good manners in using Facebook indicates the need for people to employ reflexivity in everyday relating to others. A search for websites containing online advice about Facebook etiquette was conducted using the Google internet search engine. The search was performed 18 times between 7 December 2008 and 20 March 2009, using the terms: 'Facebook etiquette privacy feelings'. Search engines do not necessarily find all relevant web pages and the reliability of their recall cannot be calculated given how fast the internet changes (Oppenheim et al. 2000). It is therefore not possible to establish how representative the results returned are, but the large number of results provide a broad range for selection. The numbers of results returned each time ranged from 117,000 on January 13 , to 620,000 on March 20. I randomly chose the first, fifth and tenth result on each page and each time the search was performed the selection restarted on the page following the last selection, until the 28th page was reached. At that point the data was reaching saturation point, with the same pages starting to appear again and later results were not about Facebook etiquette. In this way 83 links were selected, 34 of those were not relevant, and 4 were repeats. This leaves a sample of 45 sites, mostly blogs (and comments) or online articles about Facebook etiquette. Ethically it is unclear how 'public' some online material is (Baker and Whitty 2008; Beer and Burrows 2007; Hookway 2008). Those commenting on blogs may not expect an audience beyond their small user community so their names or nicknames have been changed to give greater anonymity as far as is possible with sources available online. The writers of blogs are deemed to be 'publishing' their writing and are therefore treated like off line published sources. This is not a virtual ethnography, and no covert participant observation was undertaken but I have a Facebook profile which helps give some familiarity with Facebook and assists in making sense of the data.

3.2 The forty-five texts analysed range from blogs or blog threads [2], to articles in online magazines and newspapers. They are almost all Western, and despite 70 per cent of Facebook users being from outside America (Facebook 2011), these pages are mostly from the US. A few are from the UK, Canada, and Australasia. This reflects the underwhelming levels of internet access outside of the economically privileged nations, but is also appropriate given that this paper uses work on the civilizing process in Europe, which can apply with some variation to white settler former colonies (see Mennell 2007). Although there may be a discrete sociogenesis to emotionality in each of the countries covered, the transnational and virtual nature of Facebook makes it possible to discuss a broadly shared 'netiquette'. Unlike the 
manners books Elias and Wouters refer to, these texts are not written by 'experts' and I make no claim to them being the most authoritative or popular sources. Some like Hardey's (2008b) are popular blogs, others are more obscure. Yet, taken together, the large number of relevant results on Facebook etiquette indicate that many people turn to the internet for answers about social/emotional norms. The volume of comments made on this topic when raised by bloggers also indicates that these are popular places to deal with Facebook etiquette.

3.3 Advice on etiquette is to some extent democratised by the participatory possibilities of the internet. Social network sites are a form of social media focused on interacting with others (Hardey 2008a: 54). They are part of Web 2.0, a new more user generated version of the internet. With social media the distinction between writers and audience breaks down (Beer and Burrows 2007). Instead of 'experts' informing the public about proper manners, people can consult various online communities and seek a range of opinions about what is proper, and 'think about this [social media etiquette] together' (Brogan, 2007: July 9; See also Hartman 2008; Zorn 2008). Although only some of the data is presented here, readers can explore further if they wish because it is retrievable, being available online (see Stanley and Wise 2006). A number of themes arise from a careful reading of online Facebook advice, the first of which relates to norms of friendship now requiring an emotional closeness that is problematic where there are differences in social status.

\section{Emotionally close friendships and status}

4.1 Facebook etiquette illuminates how emotionally close friendships are valued in contemporary life, but such closeness is only really achievable where friends share a similar social position. Manners are used not to show superiority but to reinforce egalitarian principles. This has wider relevance because of the belief that the difference between Facebook and the 'real' world is negligible (cf. Hardey 2008a). Chris Brogan, an American consultant on social media, wrote a blog 'Considering social network etiquette' and one response is a typical example of this belief:

[T]here should be fundamentally little difference between what you would do online or offline.... Remember, you are talking to real people with real feelings, and being kind and considerate of others is always better than being rude, or nasty or simply callous (Wilmena cited on Brogan, 2007: July 9; see also Bryant cited on Majendie 2008). [3]

4.2 Tamara Weinberg (2008: December 10) agrees in her etiquette handbook that '[s]ocial media mimics real relationships'. These relationships are not part of the same hierarchies and rules of the past and potentially anyone can become a friend. Users are typically counseled to only 'friend' people they know (Weinberg, 2008: December 10; see also Grant et al. 2007; Jackson 2008; Majendie 2008; Zorn 2008), but it is unclear how well you have to know someone to become friends. In responding to a Chicago Tribune blog in which journalist Eric Zorn asks for help navigating Facebook, David seems to think that some change in practice is occurring:

I lecture on [social networking sites and] as most adults have noted, I only accept people I know. ... My students are split on this point, with more and more leaning to no strangers. People take on all comers when new (few friends online and lots of novelty), and back off after awhile (cited on Zorn 2008; see also Jarvis 2007).

4.3 However, more restraint in making friends online is sometimes advised, as in one British blogger's guide to Facebook which cautions that:

The potential friend needs to be suitably open and receptive to such a [friend] request. It could be that in 'real life' you're not such great friends after all - as a rebuff on Facebook is as real as it gets! Perhaps time to look for a healthier connection - one-on-one in the pub/following a leisure pursuit/incidental meeting in the street, rather than a forced 'be my friend' show' (Hardey 2008b: December 3).

4.4 Not everyone agrees and another response to the Tribune blog highlights how some people might use Facebook to display popularity and increase status:

I usually accept all friend requests. Random request (sic) are kind of weird, but it doesn't really bother me that much. Plus, being friends with someone on Facebook lets you add nice little anecdotes in every day conversation: "I was walking to class with Peter when-" "Oh, he's so cute! We're facebook friends." (Margaret cited on Zorn 2008).

4.5 The New York guide to urban etiquette warns however, that having too many friends may not look good:

Can you reject a Friendster, Facebook, or MySpace friend request from someone you know? No. It's not as though adding someone to your online social network costs anything: The only potential damage is to the perceived quality of your accumulated friends (New York Guides 2009).

4.6 Status differences between 'friends' certainly still call for more emotional distance and greater formality. According to a campus magazine, University lecturers or Professors, for example should:

[L]imit participation with students on applications - at least to some degree. Go ahead and compare your movie taste with your students, if you want - but don't send them good karma and sushi and other Facebook knickknacks on a daily basis. Students, this goes for you too. Don't "rock the granny panties" with your professor on SuperPoke' (Rockler-Gladen, 2008; see also Alison cited on Zorn 2008). 
4.7 You need to consider who you are interacting with and the social context particular to different sites. One man notes this in responding to Brogan's blogged request for input on social media etiquette:

$[T]$ here are class differences and that means manners differences. I wouldn't dream of (for example) using ** profanity in jest ${ }^{\star \star}$ within Linkedln [a networking site for professionals], but I certainly would in MySpace [a site originally intended for sharing music and popular with teenagers], where it's de rigeur' (Dave cited on Brogan, 2007: July 9).

4.8 Where there are clear differences in status, being 'friends' is more difficult. Many people are aware of this, as one American journalist explains:

In a recent online Globe and Mail poll, 84 per cent of nearly 5,200 respondents answered no to the question of whether they would add their boss to their list of Facebook friends (Dunfield 2008; see also Diaz 2008; Ray cited on Zorn 2008).

4.9 Two responses on the Chicago Tribune blog thread cited earlier suggest potential problems in friending those in authority over you (like bosses) and those over whom you have some authority (like kids):

you can friend your kids, but bosses and teachers can get weird. I will not friend my bosses, ... you have to watch for professionalism, esp (sic) when you are beyond high school (Alison cited on Zorn 2008; see also Dunfield 2008).

[Whether it is proper to friend your kids, boss or teacher] really depends on the relationship you have with that person in real life (Corrine cited on Zorn 2008, see also Cate)

4.10 Another respondent to the same thread, advises: 'maybe not [friend] your kids. That would be embarrassing' (Lisa cited on Zorn 2008). Indeed the potential for embarrassment is mentioned in most of the advice on this topic and the more emotive and 'fun' registers employed with peers might need to be restrained in relating to those in authority.

4.11 This kind of advice about social networking can reveal much about current emotional norms, especially around friendships. Online friends should consider each other's feelings in the same way as offline, and although emotional closeness is encouraged with 'real' friends, where there are status differences more cautious self-expression is advised. Social media bridging of social distances is likely to be limited if people are trying to display themselves as having quality friends and merely reinforcing offline friendship groups online. This must keep networks quite homogenous, reinforcing social divisions, especially between classes. However, social networks tend to favour ideals of friendship as an egalitarian, intimate and sometimes playful type of relation and despite the problems noted online networks often involve complex webs of relations to others.

\section{Emotions within relational complexity}

5.1 Online networks are emotionally fraught because they are usually 'an unholy collection of people who, in everyday life, you'd probably go to great lengths to keep apart' (Marsden 2008). One solution is to be careful about who you 'friend' in the first place. Some suggest avoiding confusion by keeping Facebook for your peers, and maybe family. Sometimes it is thought necessary to friend to avoid awkwardness, but usually the advice is to friend someone because of a 'real' emotional connection. Commenting as part of the Tribune blog thread, 'RS' articulates this and the other bloggers referenced say similar things:

Facebook friends [are] people you know and don't dislike. For example, I didn't accept a friend request from a high school pal who I had a major falling out with a few years ago. But some people I know have mended their feuds by becoming friends on Facebook. ... [l advise you to] accept everyone as a pal because you never know when you might run into this person in the future (rs cited on Zorn 2008; see also Doctorow 2007; Dunfield 2008).

$5.2 \mathrm{It}$ is clear that many people do not friend all comers, but manage their networks, as Corrine says in the same blog thread:

I'm a little selective with my friending. Not that it happens too often, but I don't want to friend random strangers. (Corrine cited on Zorn 2008; see also Jackson 2008; Alba cited in Jernigan 2008).

5.3 Another way of 'managing' the potential role conflict (Goffman 1961) of diverse audiences on your network is to edit posts, as 'Miss Manners' (otherwise known as Judith Martin) recommends in her US newspaper advice column:

Online postings should contain only what you might freely show new acquaintances without embarrassing others or (as an astonishing number of people need to be told) themselves' (Martin, 2008: September 18; see also Bilberry 2008; crunchmonster and SamSmith cited on Ask MetaFilter, 2007: September 17; Dunfield 2008; Mooney 2007).

5.4 A common suggestion for avoiding embarrassment or misinterpretation is to use the 'Limited Profile' option. This means 'you can reveal to select individuals a limited version of your profile!' (Mooney 2007; see also Hardey 2008b; Lisa cited on Zorn 2008; MayBe and ShortMay cited on Ask MetaFilter, 2007: September 17). They then only have access to selected information. Age differences, kinship ties and working relations can make friendship difficult, as already noted. Using a limited profile is a key way to cope as three respondents to Zorn's Tribune blog indicate: 
I've found that older people who are newer to facebook often misinterpret things. .... Because of the possibilities for these types of confusion, it's often better to have a "limited profile" that has only minimal information for work colleagues (Lisa cited on Zorn 2008).

Family member and boss friendships can get sticky too. Perhaps your kids can keep you on limited profile .... You can also put your boss on limited profile as well. That way, you can accept them as friends and not hurt their feelings (rs cited on Zorn 2008).

At the very least, create a limited profile, which can be sanitized for your boss, coworkers, etc. (Nathan cited on Zorn 2008)

5.5 However, these and other contributors arguably provide not just strategies for managing emotions in Facebook relations, but highlight the reflexivity involved especially when drawing attention to the 'tongue and cheek (sic)' aspect of social media and its rules of etiquette (Hardey 2008b; see also Mooney 2007). One respondent on Zorn's blog for the Tribune says:

You're taking the whole "facebook etiquette" thing way too seriously. Facebook is a great way to procrastinate and it appeals to the voyeur in all of us, but that's about it (Nathan cited on Zorn 2008).

5.6 Other sources point out that 'students aren't always serious about the things they post there [on Facebook]' (Stuart 2006; see also Lamsback 2007). Some writers like one journalist writing for an online lifestyle magazine, make fun of the seriousness of advice given:

Debrett's says wait 24 hours before accepting a friend request, so you can think it over. But maybe a better strategy is to leave them hanging. Then nonchalantly reject their request.

They'll cope. It's only social networking, after all (Marsden 2008; cf. Hartman 2008).

5.7 Role conflict can help in understanding these discussions about how to present a suitable self to a diverse network because 'we are led to consider mechanisms for avoiding such conflict or dealing with unavoidable conflict' (Goffman 1961: 91). The chief mechanisms for avoiding role conflict are evident in the three types of typical advice given on dealing with diverse audiences. The first type of advice recommends avoiding conflict by restricting one's audience and not friending bosses, co-workers, parents, ex-partners or kids (see Dunfield 2008; Hardey 2008b; SamSmith cited on Ask MetaFilter 2007: September 17, VieOnYva cited on Etiquette Hell 2009). Secondly, users are advised to restrict, or edit, what is posted (e.g. Martin 2008; Ask Metafilter 2007; Rockler-Gladen 2008). Thirdly, it is recommended that people employ the limited profile (Money 2007; Nathan cited on Zorn 2008). Segregating your audience, can also be done by using different social network sites for different audiences (see Dave cited on Brogan 2008, July 9). The diversity of audiences can cause problems because, for example, older users may 'misinterpret' postings (see Lisa cited on Zorn 2008). This highlights the swift succession of 'generations' within the rapidly changing technologies and associated practices (Beer and Burrows 2007). However, older technologies and practices do not necessarily disappear and there is a complex layering of their use in people's interactions (Wilding 2006). For example, David (cited on Zorn 2008) claims that his students are 'more and more leaning to no strangers' in their practices, but some like Margaret (cited on Zorn 2008) are still fairly free in their friending. They may not be taking Facebook friendships very seriously and adopting a more playful approach, using humour to deal with or avoid conflict. Playful or serious, these are as much attempts to reflexively relate to others as to fit emotions to feeling rules, because norms about how to feel are now frequently uncertain (Holmes 2010).

5.8 Emotions are managed not simply around uncertain rules but according to complicated sets of relations. The blurring between categories of kin and non-kin (Pahl and Spencer 2004, Simpson 2006) can complicate rather than simplify friendship. Status differences continue within an informalizing of manners applying more to peer-to-peer than familial, educational or working relationships. Friending your kids might be embarrassing (Lisa cited on Zorn 2008); students are advised not to 'rock the granny panties' with their lecturers (Rockler-Gladen 2008) and the general recommendation is to 'watch for professionalism' (Alison cited on Zorn 2008) if friending your boss and co-workers. People are advised to consider their audience. Another way to cope with the complications of social networking is to get rid of 'friends'.

\section{Emotional reflexivity: Defriending}

5.9 Advice about defriending on Facebook further illustrates the need for considerable emotional reflexivity in online (and offline) networking. This means having to interpret one's own and others' emotions.

Defriending involves removing someone from your list of friends, so they can no longer freely view your profile. Facebook does not inform people when they are defriended and if they have a large number of 'friends' they may not notice. Nevertheless there is a possibility they might, and defriending or 'deleting' is often advised against, as in this example from an online advice site attending to Facebook etiquette:

[T]ry to refrain from deleting [friends]. If not out of consideration for their feelings, then at least out of consideration for a potentially awkward run-in with them in the future (eHowlnternet Editor, n.d.; see also Hardey cited on Kaufman 2007; Jackson 2008; rs cited on Zorn 2008).

Potential embarrassment might deter defriending, but others like this US journalist think:

If you don't want to create any hard feelings, you can also accept all friend requests, but then quietly remove those you don't want (Dunfield 2008; see also Lisa cited on Zorn 2008). 
embarrassment and discomfort feature strongly. One reason for defriending might be because 'your Facebook friend doesn't adhere to Facebook etiquette' (eHowlnternet Editor, n.d.). 'RS' agrees in his comments on the Tribune blog thread:

'[If] you've accepted a stranger as your friend and they deface your wall[ ${ }^{[4]}$, it's time to say goodbye' (rs cited on Zorn 2008; see also Etiquette Hell 2009).

5.11 Similarly, people who inspire discomfort by being 'creepy and weird' (Candy cited on Yelp 2008) are mentioned as legitimate targets for defriending, as seen in Tina's contribution to a Yelp review site comparing Facebook and Myspace:

There is nothing in life that says you can't delete someone if you aren't comfortable with them (Tina cited on Yelp 2008; see also Simon and Casey cited on Yelp 2008)

5.12 Lisa makes a similar comment in response to the Tribune blog. She explains that:

if you're creepy, ie (sic) invite me to New Hampshire to smoke pot with you and your friends (true story), I defriend. Easier than rejecting outright and sneakier because it doesn't ever notify someone that they've been defriended (Lisa cited on Zorn 2008).

5.13 Chris Brogan also advocates such an approach, in his blog on etiquette:

My theory of weirdos is simple. Drop them quietly, softly, and without fanfare. If there's a way to let them stay friends on a service, but remove their ability to see your updates, cool. If not, drop them quietly (Brogan 2007, July 9).

5.14 Individuals are being advised to reflect and act (be reflexive) based on how they feel about others. 'Creepy' and 'weird' epithets appear to be understood to designate someone who has sufficiently breached interactional conventions for another person to feel ill at ease. Often what is 'weird' about an offender is not really explained, but this does not prevent advice being given to break off relations with them - albeit 'quietly' (Brogan 2007; see also Dunfield 2008).

5.15 Defriending may also be advised where there is no 'real' relationship or friendly feeling. An anonymous wiki technology based blog recommends reflexivity in relation to former girlfriends and boyfriends:

If you are just saying that [you can still be friends with your ex-partner] so you can Facebook stalk them, do yourself a favour and just delete them (Anonymous 2008; see also Hardey 2008b, September 3; Kaufman 2007).

5.16 A respondent to the Yelp thread already mentioned appears to think that if you have negative feelings about someone then you should defriend. His advice is to 'delete everyone whom you do not have good memories of/ cannot recall' (Arthur cited on Yelp 2008). This philosophy seems to be shared by Marlene, who advises:
[defriend] [i]f they are inappropriate, or ugly (I deleted a guy who was ugly, my poor friend in Tampa), he just couldn't be there, ex-husband's family, delete people who shouldn't know your business. My philosophy is that facebook is not myspace, facebook is a place for friends and intimacy with those selected friends. I deleted my sister because she was jealous of me (Marlene cited on Yelp 2008).

5.17 This view of Facebook as, at least ideally, a space for 'positive' intimacy with 'real' friends appears to be quite widely accepted and the defriending practices described show emotional reflexivity in operation as people consider who their 'real' friends are. Although some 'have mended their feuds by becoming friends on Facebook' ( $r$ c cited on Zorn 2008), generally conflict is avoided. Anyone who 'you do not have good memories of' goes (Arthur cited on Yelp 2008) and for some it is acceptable to defriend anyone you dislike, or is ugly or jealous of you (Marlene cited on Yelp 2008). Nevertheless, the advice suggests defriending quietly so as not to hurt people's feelings. Deliberately informing people they have been defriended is frowned upon, as evident in Facebook policy and the site controllor's adverse reaction to a Burger King Promotion described by a US journalist:

[The] Whopper Sacrifice campaign, ... offered a free hamburger to anyone who severed the sacred bonds with 10 of the friends they had accumulated on Facebook. Facebook suspended the program because Burger King was sending notifications to the castoffs letting them know they'd been dropped for a sandwich (or, more accurately, a tenth of a sandwich) (Quenqua 2009).

5.18 Facebook stopped the Whopper sacrifice campaign, not because it objected to commercializing friendship - which might be a little hypocritical, but because the site owners have always wanted to avoid any association with individuals' decisions about defriending. Not shy of suggesting 'people you might know' and want to friend, Facebook does not propose people for defriending, nor tell anyone whom you do delete. Guidance about defriending without inflicting too much emotional pain has to be sought elsewhere.

5.19 Defriending practices seem to show a cold-hearted attitude to one's friends but in fact may indicate the expanded definitions of friendship that apply on Facebook where 'friends' may include long lost high school chums, work colleagues, your Grandmother and a nice person you met at a conference last year. It may be relatively easy to defriend ten of these less intimate contacts without emotional fallout. Some recommend defriending as a sort of emotional and social housekeeping (see Hardey 2008a). Friendships involve more than liking each other (Allan 1998; Pahl 2000), and many of those discussing Facebook 
etiquette agree that it is not as simple as getting rid of friends you dislike. Some may have dumped a few 'friends' for 'a tenth of a [Burger King] sandwich' (Quenqua 2009), but it is unlikely that 'real' and close friendships were ended that way. Trimming one's list of 'friends' is only necessary and possible within the more expanded and sometimes confused definitions of friendship which are encouraged by social media, but not confined to them (see Pahl and Spencer 2004). Given the close association between real and online networks, defriending may be needed to keep networks a manageable size (Hardey 2008a). Connections should preferably have some 'quality', some depth of emotion rather than being a 'forced be my friend show' (Hardey 2008b). This indicates that expanded definitions of friendship (Budgeon 2006, Pahl and Spencer 2004, Spencer and Pahl 2006) might prompt new ways of reflecting and acting on feelings for others.

5.20 'Good' manners require a reflexive ability to interpret others' and one's own emotions which not everyone possesses equally. The discussions show that 'an astonishing number of people need to be told' to take care in what is posted online (Martin 2008). What is felt as a breach of manners sufficient to defriend will differ according to the situation and the shifting etiquette by which various groups guide their interactions. Teenagers on the MySpace social network seem to delete 'friends' in a fairly relaxed fashion, but this may be because their 'friends' are likely to include people not physically present in their lives and with whom bonds are fairly superficial (see Holland and Harpin 2008: 125). Although there are general social rules, some vary across different social groups and it may be a clash of (sub)cultures or classes that causes discomfort. An invitation to smoke pot in New Hampshire might be cool for some and 'creepy' for others (Lisa on Zorn 2008). Reflexivity is relational and there are social and cultural differences in how people feel their way in a world where intimacy is rapidly altering.

\section{Conclusion}

6.1 This analysis of Facebook etiquette indicates that a variety of emotional alternatives are possible and there is a need for considerable emotional reflexivity in navigating relational and emotional norms. Beer and Burrows (2007) argue that technologies change so quickly that sociologists cannot keep up. Neither it seems can the people using them and reassurance is sought from their user communities. This rapid change (see also Oppenheim et al. 2000) means that analysis of a few years of web material about Facebook etiquette can cover substantial change compared to the slower paced alterations in manners documented by Elias and Wouters. Elias interpreted these changes as constituting a formalization of manners in which bodily and emotional self-restraint grew in importance. Wouters argued that the twentieth century saw a relaxing of etiquette and an emotionality that was diversified and democratized, but also reliant on more individual reflexivity. Online as offline presentation of self requires dealing with a world where friendship has become considered an ideal kind of relationship, focused more on egalitarian forms of connection (Roseneil 2005). However, it is difficult to know who to count as 'friends' within current complex and shifting social patterns of relating to others. Especially difficult can be shifting between the more formal manners still usually expected in relating to those of 'higher' status and the informality required by friendship with peers. It can be emotionally difficult to manage diverse networks, but people friend selectively and edit and limit their posts and profiles with some 'friends'. Many are playful and funny in their use of social networks, although role conflict is often an issue.

6.2 Online rules of etiquette are expected to follow those offline and it is still the case that people friend and defriend others for 'social reasons' (Doctorow 2007). Users may be advised to exercise self-restraint in avoiding rudeness or nastiness, partly because general principles of pacification apply. There is the 'fear of a potentially awkward run in with them in the future' (eHow Internet Editor, 2001). Turning down friend requests needs to be carefully done as part of displaying a civilised self, which involves maintaining the 'quality of your accumulated friends' (New York Guides 2009). Those overly free in friending may be accused of 'friend farming' (collecting friends to look good) (Hardey 2008a: 132), and Margaret's (cited on Zorn 2008) strategy of accepting all friend requests may lead to her being labelled a Facebook 'whore', who has too many friends and is too interested in self-display (Holland and Harpin 2008: 126-8). Equally, although internet relations can involve exchange relations as well as friendship, using Facebook for selling or spamming is not approved by most users (see Bilberry 2008; Quenqua 2009). Etiquette evolves in relation to others.

6.3 Emotional reflexivity is required to enable navigation of patterns of relating where hierarchies are less clear and where family, colleagues and a variety of peers might all be counted as 'friends'. This reflexivity is at work as individuals communicate about whom to exclude as friends and why. The potential emotional consequences of severing friendship ties are still thought to be serious if there is a 'real' intimacy. The considerable amount of discussion around defriending is a clear indication of the emotional pitfalls attending complex relationality in the twenty-first century. It is hard to avoid embarrassment and to keep relations 'comfortable' and 'real' within the quickly shifting diversity of contemporary relationships.

6.4 Some informalizing of manners has occurred, but emotionality in the twenty-first century is not free of power struggles. Social constraints are more varied and uncertain, but still centre around status relations within key social settings such as family, education and work. Users of social networking sites like Facebook debate how to act within a range of situations in which the guiding force of tradition has considerably lessened and greater complexity emerged. Relationality is more diverse but not necessarily more fluid and flexible. People are compelled to employ an emotionalized reflexivity in order to behave 'appropriately' in the range of types of interactions they experience. They reflect and act partly according to their perception of how they and others feel within particular interactional contexts. The complex diversity of these contexts within contemporary life puts emotional reflexivity at the heart of everyday life and at the centre of social reproduction (Holmes 2010).

6.5 Emotional reflexivity is employed with varying degrees of subtlety and 'success' as people navigate friendships and other relationships. Why some might employ emotional reflexivity more effectively is not clear from this data and requires further research. It is clear that thinking, feeling and acting emotionally 
have to be done around the possibilities and constraints of particular sets of social relations. Within expanded definitions of friendship, differing social status can still make friendships a problem and the sheer plethora of possible friends requires reflexive decisions not based on rational choice, but made by discussing, deliberating and feeling a way through connections and disconnections.

\section{Notes}

1 Historians have questioned too much reliance on texts prescribing how people should behave because they may bear little relation to how people do behave. Yet from a sociological point of view it is precisely the blurry and shifting line between norms and actions that fascinates (cf. Seidman 1991: 6).

$21 \mathrm{~A}$ blog is a 'personal website, based on posted entries that are displayed in a chronological order' (Hardey 2008a: 56). A blog thread is one post together with the comments received from readers.

${ }^{3}$ I give the reference for the quotation provided and then reference other similar examples. Links for these can be found in the reference list if readers wish to explore further.

${ }^{4}$ The 'wall' is a space where any of your friends can post messages and photos and comments for all others who have access to your profile to see.

\section{References}

ALLAN, G (1998) 'Friendship, sociology and social structure' Journal of Social and Personal Relationships 15(5): 685-702. [doi:10.1177/0265407598155007]

ANONYMOUS, (2008) 'Defriending your ex' 1 September, Wiki techonology. Accessed 24 February 2009 at $<$ http://facebookstalker.wikia.com/wiki/Defriending_your_ex>.

ASK METAFILTER (2007) 'Photo uploading etiquette' Ask MetaFilter: Querying the Hive Mind, September 17-18, 2007. Accessed on 4 November 2008 at <http://ask.metafilter.com/71793/Photo-uploadingetiquette>

BAKER, A J and Whitty, M T (2008) 'Researching romance and sexuality online: Issues for new and current researchers' pp 34-49 in S. Holland (ed) Remote Relationships in a Small World, New York: Peter Lang.

BAUMAN, Z (2003) Liquid Love: On the Frailty of Human Bonds, Cambridge: Polity Press.

BECK, U and Beck-Gernsheim, E (2002) Individualization: Institutionalized Individualism and its Social and Political Consequences, London: Sage.

BECK, U and Beck-Gernsheim, E (1995) The Normal Chaos of Love, Cambridge, Polity Press.

BEER, D and Burrows, R (2007) 'Sociology and, of and in web 2.0: Some initial considerations' Sociological Research Online 12(5): <http://www.socresonline.org.uk/112/5/17.html>

BILBERRY, K (2008) 'Dual nature - using your facebook profile to sell your real estate' May 29, Ezine articles, Accessed 3 March 2009 at <http://ezinearticles.com/?Dual-Nature---Using-Your-Facebook-Profileto-Sell-Your-Real-Estate\&id=1211259>

BOYD, d m (2008) 'Why youth ? social network sites: the role of networked publics in teenage social life', pp.119-142 in D. Buckingham (ed) Youth, Identity, and Digital Media, Cambridge, MA: MIT Press.

BOYD, d m and Ellison, N B (2007) 'Social network sites: Definition, history and scholarship' Journal of Computer Mediated Communication 13(1): 210-30. [doi:10.1111/j.1083-6101.2007.00393.x]

BROGAN, C (2007) 'Considering social network etiquette' chris brogan: community and social media (July 9). Accessed on 9 December 2008 at <http://www.chrisbrogan.com/considering-social-network-etiquette/>.

BUDGEON, S (2006) 'Friendship and formations of sociality in late modernity: the challenge of 'post traditional intimacy' Sociological Research Online 11(3):

$<$ http://www.socresonline.org.uk/11/3/budgeon.htmls.

BURKITT, I (1996) 'Civilization and ambivalence' British Journal of Sociology 47(1): 135-50.

[doi:10.2307/591120]

DAVETIAN, B (2005) 'Towards an emotionally conscious social theory' Sociological Research Online 10(2): $<$ http://www.socresonline.org.uk/10/2/davetian.html>.

DIAZ, J (2008) 'Facebook's squirmy chapter: site's evolution blurs line between boss and employee', April 16 , boston.com, The Boston Globe. Accessed on 20 January 2009 at

<http://www.boston.com/jobs/news/articles/2008/04/16/facebooks_squirmy_chapter/>.

DOCTOROW, C (2007) 'Facebook will sink under the weight of socially obligated "friendships"', Nov 26,

BoingBoing: A Directory of Wonderful Things, Accessed on 13 January 2009 at 
DUNFIELD, A (2008) 'Buddying up to the boss on Facebook', July 9, Technology: The Globe and Mail, globeandmail.com, accessed 27 Jan 2009 at

<http://www.theglobeandmail.com/servlet/story/RTGAM.20080709.wcafacebook09/BNStory/Technology/home/? pageRequested=all>

EHOW INTERNET EDITOR (n.d.) 'How to have good facebook etiquette' on eHow: How To Do Just About Everything. Accessed 7 October 2008 at <http://www.ehow.com/how_2252686_have-good-facebooketiquette.html>.

ELIAS, N (2000/1939) The Civilizing Process: Sociogenetic and Psychogenetic Investigations, Oxford: Blackwell.

ETIQUETTE HELL (2009) 'Handling a facebook snoop' January 18, Etiquette Hell Forum, Accessed 19 March 2009 at <http://www. etiquettehell.com/smf/index.php?topic=50312. msg1182370>

FACEBOOK (2011) 'Press room: Statistics' Accessed on 4 Jan 2011 at <http://www.facebook.com/press/info.php?statistics>

FOUCAULT, M (1979) Discipline and Punish: The Birth of the Prison, London: Penguin.

FOUCAULT, M (1990) The History of Sexuality: Volume One, An Introduction, London: Penguin.

GIDDENS, A (1992) The Transformation of Intimacy: Sexuality, Love and Eroticism in Modern Societies, Palo Alto, CA.: Stanford University Press.

GOFFMAN, E (1961). Encounter: Two Studies in the Sociology of Interaction, Indianapolis, IA: BobbsMerrill.

GOFFMAN, E (1987) The Presentation of Self in Everyday Life, Harmondsworth: Penguin.

GRANT, C, Kodama, L and Liu, C (2007) 'Two-faced Facebook', October 5, Arlingtonian, Accessed on 13 January 2009 at <http://www.arlingtonian.com/200708/issue2/ARL07082.pdf>, on 13 Jan 2009.

HARDEY, M (2008a) Seriously social: making connections in the information age, Unpublished PhD Thesis, University of York.

HARDEY, M (2008b) 'Practising a proper social demeanour: a guide to Facebook etiquette: New rules for surviving the digitally connected world' Accessed on 9 December 2008 at $<$ http://properfacebooketiquette. blogspot.com/>.

HELSPER, E J and Whitty, M (2010) 'Netiquette within married couples: Agreement about acceptable online behavior and surveillance between partners' Computers in Human Behaviour 26(5): 916-26. [doi:10.1016/j.chb.2010.02.006]

HOCHSCHILD, A R (2003) 'The commercial spirit of intimate life and the abduction of feminism: Signs from women's advice books'. In The Commercialization of Intimate Life: Notes from Home and Work, Berkeley, CA: University of California Press.

HOCHSCHILD, A R (1983) The Managed Heart: Commercialization of Human Feeling, Berkeley, CA: University of California Press.

HOLLAND, S and Harpin, J (2008) “It's only MySpace”: Teenagers and social networking online'. In Holland, S (ed) Remote Relationships in a Small World, New York: Peter Lang.

HOLMES, M (2010) 'The emotionalization of reflexivity' Sociology 44(1): 139-154. [doi:10.1177/0038038509351616]

HOLMES, M (2004) 'Feeling beyond rules: Politicising the sociology of emotion and anger in feminist politics' European Journal of Social Theory 7(2): 209-227. [doi:10.1177/1368431004041752]

HOOKWAY, N (2008) 'Entering the blogosphere': some strategies for using blogs in social research' Qualitative Research 8(1): 91-113. [doi:10.1177/1468794107085298]

JACKSON, A (2008) 'The Facebook phenomenon' Satellite Magazine, 4: 8-9. Accessed on 17 March 2009 at <http://www.satellite.ac.nz/issues/08-04.pdf>.

JARVIS, J (2007) 'Howie and friends on facebook' July 9, Buzzmachine. Accessed on 28 October 2008 at <http://www.buzzmachine.com/2007/07/09/howie-friends-on-facebook/>.

JERNIGAN, J (2008) 'When you don't want to be Facebook friends. Connecting with your past can bring up those old, uncomfortable feelings' Nov 18, msnbc. Accessed 24 February 2009 at <http://www.msnbc.msn.com/id/27775484/>

KAUFMAN, D (2007) 'Friends, foes and Facebook', 27 November, Stuff.co.nz, Accessed on13 Jan 2009 at <http://www.stuff.co.nz/stuff/4289877a11275.html>. 
LAMSBACK, T (2007) 'The Wisecat: Do not be fooled by "facebook-official"' The Villanovan [Villanova University Student Newspaper] Issue date: 4/19/07. Accessed on 9 December 2008 at $<\mathrm{http}: / /$ www.villanovan.com/home/index.cfm?event=displayArticle\&ustory_id=5bb911d2-6151-4fa0-bfde317258164384>

LENHART, A (2009) 'Adults and social network websites' Pew Internet and American Life Project, January 14. Accessed 5 May 2009 at <http://www. pewinternet.org/Reports/2009/Adults-and-Social-NetworkWebsites.aspx>

LYONS, P J (2007) 'Has Facebook worn out its welcome?', Dec 7, The Lede: Notes on the News, The New York Times. Accessed on 20 January 2009 at <http://thelede.blogs. nytimes.com/2007/12/07/has-facebookworn-out-its-welcome>

MAJENDIE, P (2008) 'Manners still matter when you're poking on Facebook', June 13, Reuters. Accessed on 27 January 2009 at <http://www.reuters.com/article/internetNews/idUSL1313262220080613>

MANTOVANI, G (1994) 'Is computer-mediated communication intrinsically apt to enhance democracy in organizations?' Human Relations 47: 45-62. [doi:10.1177/001872679404700103]

MARSDEN, R (2008) 'Do's and don'ts of Facebook', June 24, Lifestyle: Independent.ie. Accessed 27 Jan 2009 at <http://www.independent.ie/lifestyle/dos-and-donts-of-facebook-1419910.html>

MARTIN, J/ Miss Manners (2008) 'Old boyfriend still hanging around in facebook photos' Chicago Tribune.com, September 18. Accessed 4 November 2008 at $<$ http://www.chicagotribune.com/features/columnists/advice/chi-miss-manners-judith-martinOsep18,0,5245323.column>

MENNELL, S (2007) The American Civilizing Process, Cambridge: Polity Press.

MILLS, T and Kleinman, S (1988) 'Emotions, reflexivity, and action: An Interactionist analysis' Social Forces 66(4): 1009-1027. [doi:10.2307/2579433]

MOONEY, H (2007) 'Musings on Facebook, vol. 1: Facebook and your co-op term' October 11, Harrison Exists: He often talks about race and popular culture. Accessed on 27 January 2009 at <http://harrisonexists.blogspot.com/2007/10/musings-on-facebook-vol-1-facebook-and.html>.

NEW YORK GUIDES (2009) The Urban Etiquette Handbook, New York Magazine, no specific date, Accessed on 3 March 2009 at <http://nymag.com/guides/etiquette/17332/index9.html>

OPPENHEIM, C, Morris, A, McKnight, C, and Lowley, S (2000) 'The evaluation of WWW search engines' Journal of Documentation 56(2): 190-211. [doi:10.1108/00220410010803810]

PAHL, R (2000) On Friendship, Cambridge: Polity

PAHL, R and Spencer, L (2004) 'Personal communities: Not simply families of 'fate' or 'choice' Current Sociology 52(2): 199-222. [doi:10.1177/0011392104041808]

QUENQUA, D (2009) 'Unfriending' a fact of life on facebook', Feb 3, TheRecord.com, Accessed 24 February 2009 at <http://news.therecord.com/Life/article/481295

ROCKLER-GLADEN, N (2008) 'Facebook, MySpace and professors: Should college instructors have social networking pages?' Suite 101.com: The genuine article. Literally, June 4 2008. Accessed on 23 December 2008 at <http://campuslife.suite101.com/article.cfm/facebook_myspace_professors>.

ROSENEIL, S (2005) 'Living and loving beyond the boundaries of the heteronorm: Personal relationships in the 21st century'. In Mckie, L, Cunningham-Burley, S and McKendrick, J (Eds.) Families in Society: Boundaries and Relationships, Bristol: Policy Press.

SEIDMAN, S (1991) Romantic Longings: Love in America, 1830-1980, New York and London: Routledge.

SIMPSON, R (2006) 'The Intimate Relationships of Contemporary Spinsters' Sociological Research Online 11(3): <http://www.socresonline.org.uk/11/3/simpson.html>.

SKINSTAD, M (2008) 'Facebook: A digital network of friends' Paper to be presented at the $24^{\text {th }}$ Conference of the Nordic Sociological Association, University of Aarhus, 14-17 August. Accessed 27 January 2009 at <http://www.nordicsociology2008.dk/Papers/Consumption\%20and\%20lifestyles/marianne\%20skinstad\%20$\% 20$ consumption\%20and\%20lifestyles.pdf>

SPENCER, L and Pahl, R E (2006) Rethinking Friendship: Hidden Solidarities Today, Princeton, N.J. and Oxford: Princeton University Press.

SPROULL, L and Kiesler, S (1986) 'Reducing social context cues: Electronic mail in organizational communication' Management Science 32: 1492-1512. [doi:10.1287/mnsc.32.11.1492]

SPROULL, L and Kiesler, S (1991) Connections: New Ways of Working in the Networked Organization. Cambridge, Mass.: MIT Press.

STANLEY, L and Wise, S (2006) 'Putting it into practice: Using feminist fractured foundationalism in 
researching children in the concentration camps of the South African war' Sociological Research Online 11(1): <http://www.socresonline.org.uk/11/1/stanley.html>.

STUART, E (2006) 'Universities use social networks to find misbehaving students' 26 May, News from the Y, BYU Newsnet. Accessed 27 January 2009 at <http://newsnet.byu.edu/story.cfm/59872>

VALENTINE, G (2006) 'Globalizing intimacy: The role of information and communication technologies in maintaining and creating relationships' Women's Studies Quarterly 34(1/2): 365-393.

WEINBERG, T (2008) 'The ultimate social media etiquette handbook' Techipedia: Tamar Weinberg, 10 December. Accessed on 16 December 2008 at <http://www.techipedia.com/2008/social-media-etiquettehandbook/>

WELLMAN, B (2001) 'Physical place and cyberplace: The rise of personalized networking' International Journal of Urban and Regional Research 25(2): 227-52. [doi:10.1111/1468-2427.00309]

WHITTY, M T (2008) 'Liberating or debilitating? An examination of romantic relationships, sexual relationships and friendships on the net' Computers in Human Behavior 24(5): 1837-1850 [doi:10.1016/j.chb.2008.02.009]

WILDING, R (2006) '“Virtual” intimacies? Families communicating across transnational contexts' Global Networks, 6, 125-142. [doi:10.1111/j.1471-0374.2006.00137.x]

WOUTERS, C (2007) Informalization: Manners and Emotions since 1890, London: Sage.

WOUTERS, C (2004) 'Changing regimes of manners and emotions: From disciplining to informalizing' pp 193-211 in S. Loyal and S. Quilley (eds) The Sociology of Norbert Elias, Cambridge: Cambridge University Press.

WOUTERS, C (1995a) 'Etiquette books and emotion management in the 20th Century: Part one--the integration of social classes', Journal of Social History, Vol. 29, No. 1, pp. 107-124.

WOUTERS, C (1995b) 'Etiquette books and emotion management in the 20th century: Part two--the integration of the sexes', Journal of Social History, Vol. 29, No. 2, pp. $325-40$.

YELP (2008) Various authors, 'Is it okay to delete someone as your friend from facebook?' Yelp Houston, Yelp: Real people, real reviews. Accessed on 16 February 2009 at <http://www.yelp.com/topic/houston-isit-okay-to-delete-someone-as-your-friend-from-facebook>

ZORN, E (2008) 'Help wanted” 7 questions about Facebook' 22 February, Change of Subject:

Observations, reports, tips, referrals and tirades, Chicagotribune.com. Accessed 20 January 2009 at $<$ http://blogs.chicagotribune.com/news_columnists_ezorn/2008/02/help-wanted-fac.html> 